Info Artikel:

\title{
CONSTRUCTIVISM AND ITS PERSPECTIVES RELATED TO TEACHING AND LEARNING PROCESS IN THE CLASSROOM : A CONCEPTUAL FRAMEWORK
}

\author{
Welly Ardiansyah ${ }^{1}$, Murwani Ujihanti ${ }^{2}$ \\ IAIN Syaikh Abdurrahman Siddik Bangka Belitung \\ ardiansyahwelly@gmail.com, anihanafi@yahoo.co.id
}

\begin{abstract}
Constructivism is a view that emphasizes the active role of students in building understanding and making sense of the information. The constructivist teaching is learner centered where students are actively involved in knowledge construction rather than mere passive listeners. Constructivists' views can be organized in two forms: psychological and social. In constructivists' view such as Piaget, students construct knowledge by transforming, organizing, reorganizing previous knowledge whereas in social constructivists' view such as Vygotsky, opportunities are provided to students to learn through social interaction in construction of knowledge and understanding. The paper is an attempt toexamine constructivist teaching and learning by providing in-depth analysis of features of constructivist theory and its two forms (psychological and social) and the organization of a constructivist classroom.
\end{abstract}

Keywords: Constructivism, cooperative learning, social interaction 


\section{INTRODUCTION}

Constructivist approach corresponds to learning by doing assuming that the more repeatedly one does something, the more efficient s/he becomes at it. It consists on different forms and activities including cooperative learning, experiential learning, problem-based learning and inquiry learning ${ }^{1}$. However, it is based on active involvement of learners and their interactions for creation of new knowledge.

Critical thinking, problem solving approach and analytical skills are assumed to be the essential constructs of higher education graduates. Equipped with such faculties and skills they construct new knowledge based on their previous experiences and involvement in learning process $^{2}$. Furthermore "knowledge is constructed through observation, reflection and interaction with the surrounding environment such as their peers, teachers or technology". It is based on strategies of effective learning and leads them to construct new knowledge by interpreting it in a particular situation. In a constructivist classroom the teacher becomes facilitator to help students in acquiring knowledge through activities ${ }^{3}$.

Students' involvement results in their effective learning. take place through one's personal involvement in learning experience. It requires them to work in groups and interact in social settings based on the principle of Vygotsky's social constructivism ${ }^{4}$. In social constructivism and asserted that social interaction among learners spurred the construction of new ideas and enhanced their intellectual development. Nonetheless to say that intellectual development and creation of ideas is associated with pedagogies ${ }^{5}$. Bruners' pedagogies included activity-based and hands-on instruction in which students were expected to use their own direct experiences and observations to acquire information and to solve problems scientifically.

\section{PEMBAHASAN}

\section{Role of Teacher in Constructivism: Teacher as an Academic Leader and Facilitator}

A teacher is considered to be the academic leader and facilitator of students. S/he recognizes their potential and helps them in right direction at right time. A constructivist approach is oriented on construction of knowledge putting students in practical situations under the guidance and tutelage of teachers. It seems to be based on the belief that learners construct their own knowledge through interaction, and the assumption that "know- ledge is physically constructed by learners who are involved [actively in learning process]" appears to be substantiating it ${ }^{6}$. Knowledge is

${ }^{1}$ Hussain, I., \& Sultan, S., "Learning by doing: Outcomes of teaching a research course through group activities", Proceedings of the Annual International Conference on Computer Science Educa-tion: Innovation \& Technology (CSEIT) 2010, 2010, p.130.

${ }^{2}$ Li, W., "Constructivist learning systems: A new paradigm”, International Conference on Advanced Learning Techniques, 2001, p.72.

3 Alesandrini, K., \& Larson, L., "Teachers bridge to constructivism”, Clearing-House. 75, 2002,

p.119.

4 Johnson, D. W., \& Johnson, F. P., Joining together: Group theory and group skills, (7th ed; Englewood Cliffs, NJ: Prentice Hall, 1999), p.82.

${ }^{5}$ Bruner, J. S., The culture of education, (Cambridge: Harvard University Press, 1996), p.106.

${ }^{6}$ Gagnon, G. W., \& Colley, M. (2001). “Constructivist learning design”, (URL 
constructed in social environments where interaction is considered to be a fundamental factor for effective teaching learning process ${ }^{7}$. Under such circumstances the role of a teacher cannot be neglected rather it becomes more significant in terms of coaching students to selecting appropriate activities for learning.

Traditionally, a teacher has been playing an active role in transferring knowledge to passive students. In new settings the stage is set for students to play an active role in learning process through activities. They feel pleasure and confidence in becoming active participant. There were study effects of constructivist learning (learner-centered) approach on weekly test scores of students as compared to students' scores in traditional or teacher- centered environment. The study further elaborated that constructivist learning helped them in enhancing their participation, level of satisfaction, enthusiasm for raising a question or responding to it, and an inclination towards scientific attitude. Constructivism makes teachers design activities and projects to be offered to the students. These may consist on service-learning and community-based projects and activities to involve students ${ }^{8}$.

\section{Effects of Constructivism on Learning}

Use of constructivist approach in education has direct effects on students learning. They are active stake holders in the process of knowledge construction and its dissemination. They participate in teaching learning process and assume responsibility of their learning by giving it their own meaning in their respective contexts. Constructivism offers students opportunities of cooperative and collaborative learning.

A study of comparing learning achievement of two groups of elementary school students found that the students who learned through social-constructivist approach to education and took a standardized test secured higher grades than their counterparts who were instructed traditionally in the classroom. The students' participation in such projects enhanced their academic performance as well ${ }^{9}$.

Constructivism involves students and they participate actively in teaching learning process through different activities. The study found that the mean achievement of the students who participated actively in teaching learning process was greater than their counterparts who attended traditional classes. The study further explained that the students spent more time in doing activities that required thinking, responding and verifying their knowledge. Therefore, active participation of

http://www.prainbow.com/cld/clds.html, 2001), p.1

${ }^{7}$ Sims, R., Dobbs. G., \& Hand, T. (2001). "Proactive evaluation: New perspectives for ensuring quality in online learning application", Conference proceedings of the 18th Annual Conference of the Australlian Society for Computers in Learning in Tertiary Education (ASCILITE), (Meeting at the Crossroads, 2001), p.512.

${ }^{8}$ Lord, T., Travis, S., Magill, B., \& King, L., Comparing student-centered and teachercentered instruction in college biology labs ( Indiana, PA: Indiana University of Pennsylvania, 2005), p.232.

${ }^{9}$ Santmire, T. E., Giraud, G., \& Grosskopf, K. (1999). “An experimental test of a constructivist educational environment", Annual Meeting of the American Educational Research Association, (Montreal, 19-23 April 1999), p.24. 
students (constructivism) was affirmed to be an efficient instructional approach for creating \& sustaining motivation and passion for knowledge construction ${ }^{10}$.

\section{The Impact of Social Interaction on Student learning}

Today's students have taken to social networking like fish to water; yet, from our perspectives, there is little social interaction taking place in many of today's classrooms from kindergarten through college. The model of discourse in most classrooms is a one-way communication from the teacher to the students. For example, the first thing one kindergartener said to his mother after his first day of school was: "All teachers do is talk, talk, talk ${ }^{11}$." He said the same thing after his first day of high school and his first day of college. His observations are not uncommon. As early as 1984, he wrote "the data from our observations in more than 1,000 classrooms support the popular image of a teacher standing in front of a class imparting knowledge to a group of students". Smith wrote in 1998 that teachers talk $90 \%$ of the time in classrooms. Teachers expect students to sit hour after hour, taking notes, and answering the occasional question with little interaction with peers.

The concept of teachers doing all of the talking in classrooms is in direct contrast to the philosophy that learning is primarily a social activity and the idea that the person who is doing the work is the person doing the learning ${ }^{12}$. Teachers expend a lot of energy preparing lectures. They must read various texts and synthesize the information, pick out the most important points and organize them in a cohesive manner, write lecture notes, and then deliver the information to students who sit passively often thinking of everything but what the teacher is saying. Who is doing all of the work in this process? The teacher. The teacher is the one reading, writing, thinking, speaking, and therefore, the one who is learning. contend that Teachers need to shift "the burden of learning from teachers' shoulders to students ${ }^{13}$. Students need to be a gradual release of responsibility for control of the discussion from teacher to students. It is the student who should be doing most of the work $^{14}$.

One way for students to shoulder the responsibility for learning is for them to be the readers, writers, speakers, listeners, and thinkers in the classroom through active engagement in social

${ }^{10}$ Pratton, J., \& Hales, L. W., “The effects of active participation on student learning”. Journal of Educational Research, 79, 1986, p. 210.

${ }^{11}$ Goodlad, J., A place called school, ( New York: McGraw-Hill, 1984), p.105.

12 Hurst, B., "Person working equals person learning”. Journal of Reading Education, 23 (3), 1998),

p.23.

${ }^{13}$ Vacca, R.T., \& Vacca, J.L., Content area reading: Literacy and learning across the curriculum, (7th ed; Boston: Allyn and Bacon, 2002), p.7.

${ }^{14}$ Wilkinson, I.A.G., Soter, A.O., \& Murphy, P.K., "Developing a model of quality talk about literacy text”, in M.G. McKeown \& L. Kucan (Eds.)., Bringing reading research to life, (pp.142-169). New York: The Guilford Press, 2010), p.156. 
interaction with others ${ }^{15}$. For the purpose of this study, they define social interaction as meaningful dialogue among learners. Socially interactive learners are engaged learners ${ }^{16}$. Students learn more when they are able to talk to one another and be actively involved. In short, social interaction is vital to the learning process ${ }^{17}$.

Years ago, reading, writing, listening, and speaking should be kept whole (as in whole language) instead of teaching each one separately. He promoted that reading, writing, listening, and speaking should be incorporated into everything students do throughout the day. Because reading, writing, and social interaction are part of everyday life in the real world, it does not make sense for classrooms to be social interaction-free zones where the teacher talks while students listen $^{18}$. Reading and writing cannot be separated from speaking, listening, and interacting, on the one hand, or using language to think about and act on the world, on the other ${ }^{19}$.

The teachers of another era spent so much time keeping their classes quiet and then wondered why so many students were terrified of occasional oral reports and even continued into adulthood to be uncomfortable speaking to a group. She stated "teachers and principals of the past who worked hard to keep children quiet (myself included) did not know how critical social interaction and collaboration are in learning. They also may not have known how to incorporate social interaction into their classrooms. The problem is not that students are unwilling to talk; many teachers say they spend the better part of their days trying to get their students to stop talking (whether in person or texting). The problem is getting the students to talk about the subject at hand $^{20}$.

\section{Zone of proximal development}

One of the most important theories of Vygotsky involves the "zone of proximal development." He proposed that children, in any given domain, have actual developmental levels, which can be assessed by testing them individually. He further contended that there is an immediate potential for development within each domain. The difference between the two is called the zone of proximal development. It is suggested that the distance between the actual developmental level as determined by independent problem solving and the level of potential development as determined through problem solving under adult guidance or in collaboration with

15 Alvermann, D.E., \& Phelps, S.F., Content reading and literacy: Succeeding in today's diverse classrooms, (4th ed; Boston: Allyn Bacon, 2005), p.128.

${ }^{16}$ Vacca, R.T., Vacca, J.L., \& Mraz, M., op. cit., p.12.

${ }^{17}$ Routman, R., Writing essentials: Raising expectations and results while simplifying teaching, (Portsmouth, NH: Heinemann, 2005), p.207.

${ }^{18}$ Goodman, K., What's whole in whole language, (Portsmouth, NH: Heinemann, 1986), p.237.

${ }^{19}$ Gee, J. P., "Reading as situated language: A sociocognitive perspective", Journal of Adolescent \& Adult Literacy, 44 (8), 2001), p.714.

${ }^{20}$ Kasten, W.C., "Learning is noisy; the myth of silence in the reading-writing classroom", in J.R. Paratore, \& R.L. McCormack (Eds.)., Peer talk in the classroom: Learning from research, (Newark, DE: International Reading Association 1997), p.89. 
more capable peers. This implies the idea that tasks, which are too difficult for children to master alone, can be learned with guidance and assistance from adults, more-skilled children, or more knowledgeable others. The zone of proximal development captures the child's cognitive skills that are in the process of maturing, and these skills can only be honed with the assistance of moreskilled persons. Vygotsky explained that the upper limit in the zone of proximal development cannot become fruits without social interactive support from peers and teachers. Vygotsky suggested that if in the course of study, one can be assisted by more skilled persons, such as peers and teachers, his/her support level is changed. Also, as his/her peers and teachers adjust their support towards his/her guidance needs, he/she may advance in terms of his/her zone of proximal development. The process of adjusting the support is called scaffolding. Scaffolding refers to the assistance given to students in completing tasks that they cannot complete by themselves.

In Vygotsky's social constructivism, social interaction is an important way in which children learn knowledge available in their culture without needing to reinvent it by them. Parents, adults, caregivers, teachers, and peers play important roles in the process of appropriation in children's learning. Teachers and adults give direction and instructions, comments, and feedback to students. These are not passively received by students because they also communicate with teachers, conveying them their problems or their answers in an interactive manner. Children also use conversations in working with their peers in handling exercises, projects, and problems. In this way, they exchange ideas and receive information, thereby generating understanding and developing knowledge.

This process of learning is regarded as important because knowledge itself is developed through history, and it should go through appropriation in a social environment. Learning is achieved through the process of development; hence, learners should be active participants in the process of learning. Activity is important in learning; it is also a key concept in socio-cultural theories that explain the importance of doing. By engaging in meaningful activities, learners interact with peers and more knowledgeable people. Through interaction, children develop dialogues within the structure of activities; as a result, learning and development occurs. To Vygotsky, language plays an important role in learning.

\section{Constructivism and Classroom Practice}

A constructivist teacher and a constructivist classroom are distinguished from a traditional teacher and classroom by a number of identifiable qualities: the learners are actively involved, the environment is democratic, the activities are interactive and student centered, and the teacher facilitates a process of learning in which the students are encouraged to be responsible and autonomous $^{21}$. The constructivist classroom is an environment in which student will have enough time to develop mental models of the content, which will assist in moving that knowledge away from primary content area, so that it can be applied elsewhere ${ }^{22}$. The teacher is seen as a facilitator of learning, where learners are permitted to move around freely, use of time is flexible rather than structured, and evaluation compares learners to themselves rather than to peers, with de-emphasis on formal testing. Teachers need to recognize how learners use their own experiences, prior knowledge and perceptions. The constructivist classroom should be an environment based on inquiry which will leads the learners to deep understanding of the concepts under scrutiny. Social interactions and context is necessary for learning to occur. Constructivist classrooms are structured so that learners are immersed in experiences with which they may engage in interactions, invention and meaning-making inquiry.

${ }^{21}$ Gay, L.R., Educational research competencies for analysis and application, (New Jersey: Prentice-Hall. Inc., 2008), p.128.

22 Spiro, P., Constructivism in practice: The case study for meaning-making in the virtual world, (Hillsdale. Lawrance Erlbaum Publications, 2008), p.321. 
Although teachers do not necessarily follow a deliberate constructivist approach to teaching in their classrooms, a number of implications for teaching practice can be derived from it, namely: a constructivist approach recognizes the value of a child's inherent curiosity, science is viewed as a dynamic, continual process of increasing a person's understanding of the natural world, knowledge construction occurs within each individual through interaction with other people and the environment, and the teacher following a constructivist approach largely functions as a facilitator of knowledge construction and takes the following alternative roles: presenter, observer, question asker and problem poser, environment organizer, public relations coordinator, documenter and theory builder ${ }^{23}$.

In teaching and learning environment the learners' curiosity to learn should be aroused. This can be done by using attractive teaching and learning aids. As facilitators of learning teachers should guide learners to discover for themselves as they interact with the learning process. Knowledge can be regarded as an individual construction of reality through interaction with other people and the environment they live in. Constructivism is a theory of learning, not a theory of teaching. Therefore, instructional theories should translate the learning theories into instructional strategies. These instructional theories should prescribe series of strategies the teacher should follow in order to produce certain types of learner learning.

\section{Social Constructivism}

Social constructivism emphasizes the importance of culture and context in understanding what occurs in society and constructing knowledge based on this understanding ${ }^{24}$. In social constructivism school literacy learning of students of diverse backgrounds will be improved as educators address the goal of instruction, the role of the home language, instructional materials, classroom management and interaction with students, relationships with the community, instructional methods and assessment. Knowledge is actually constructed or developed by humans ${ }^{25}$.

Language and writing systems are the cultural tools developed and available to people in different societies. Learners of diverse backgrounds should be encouraged to use their home language skills as the basis for developing literacy in schools. In the social constructivism learning environment, teachers are not to leave the learners to their own devices, but are to appraise what is important for true understanding of the content and move among the learners to assist with strengthening the quality of learners' constructs. The teacher's role is to support the learners to make ideas and practices of the learning community meaningful at their respective individual levels.

${ }^{23}$ Martin, R.E. Sexton, C. Franklin, T. Gerlovich, J, and McElroy, D., Teaching science for all children, (Boston: Allyn and Bacon, 1994), p,46.

${ }^{24}$ Kim, B., Social constructivism, (New York:Routledge, 2006), p.73.

$25 \mathrm{Au}$, K.H. (2005).Social Constructivism and the School Literacy Learning of Students Diverse Backgrounds. Journal of Literacy Research.Vol 7 (30): 29-79. 
There are four general perspectives that inform how we could facilitate the learning within the framework of social constructivism, namely, cognitive tools perspective, idea-based social constructivism, pragmatic or emergent approach, and transitional or situated cognitive perspectives. In cognitive tools perspective the emphasis is on the learning of cognitive skills and strategies while the idea-based social constructivism focuses on science, mathematics and literature. Pragmatic or emergent approach asserts that the implementation of social constructivism in class should be emergent as the need arises. In transactional or situated cognitive perspectives the focus is on the relationship between the people and their environment ${ }^{26}$.

The school literacy learning of students of diverse backgrounds can improve as educators recognize the importance of students' home languages and come to see illiteracy as an attainable and desirable outcome ${ }^{27}$. Schools are the socio-cultural settings where teaching and learning take place and where "cultural tools" such as reading, writing, mathematics, and certain modes of discourse are utilized ${ }^{28}$. This theory assumes that theory and practice do not develop in a vacuum; they are shaped by dominant cultural assumptions. Teachers should use forms of assessment that reduce sources of and reflect learners' literacy achievement. Social constructivists actually view learning as a social process and knowledge as a human product. The thinking abilities of young children can be developed by interacting with adults.

From a social constructivist perspective, five explanations for the literacy achievement gap appear: linguistic differences, cultural differences, discrimination, inferior education and rationale for schooling ${ }^{29}$. Both success and failure in literacy learning are the collaborative social accomplishments of school systems, communities, teachers, students and families. In constructivism, communication or discourse processes are compared to processes of building. The emphasis is on generative acts, such as those of interpreting or composing texts. Themes in constructivist work include active engagement in processes of meaning-making, text comprehension as a window on these processes and the varied nature of knowledge, especially knowledge developed as a consequence of membership in a given social group ${ }^{30}$. Social constructivism includes the idea that there is no objective basis for knowledge claims, because knowledge is always a human construction. The emphasis is on the process of knowledge construction by the social group and the inter-subjectivity established through the interaction of the group. Social constructivist research on literacy learning focuses on the role of teachers, peers, and family members in mediating learning, on the dynamics of classroom instruction, and on the organization of systems within which children learn or fail to learn. Every day and scientific

${ }^{26}$ Kim, B., op. cit., p. 67.

27 Au, K.H., op. cit., p.29.

${ }^{28}$ Abdal-Haqq, I., Constructivism in teacher education: Considerations for those who would link

practice to theory, (Thousand Oaks. CA: Corwin Press, 1998), p.89.

${ }^{29} \mathrm{Au}$, K.H., op. cit., p.51.

${ }^{30} \mathrm{Au}, \mathrm{K} . \mathrm{H} .$, op. cit., p.53. 
concepts are differentiated, that is, the child gains everyday (or spontaneous) concepts through daily life, whereas he or she learns scientific concepts through formal instruction and schooling ${ }^{31}$.

\section{Assumptions of Social Constructivism}

Social constructivism is based on specific assumptions about reality (constructs through human activity), knowledge (human product, socially and culturally constructed) and learning (social process) $^{32}$. On the other hand, a social constructivist perspective is explicitly based on assumptions of ontology, epistemology and ideology $y^{33}$. The following are interrelated assumptions of social constructivism: (1) maintaining skepticism: holding a critical and questioning attitude about knowledge as fundamental and definite, (2) avoiding the risks of generalization: though knowledge such as the dominant professional discourses and theoretical truths can be generalized and applied across all peoples, cultures, situations, or problems, the usefulness of such is doubtful, (3) knowledge as an interactive social process: knowledge is produced within and through social discourse, (4) privileging local knowledge: local or home grown knowledge created within a community of persons (family, organisation, classroom) who have first-hand knowledge and experience of themselves and their situation is important, (5) language as a creative social process: language in its broadest sense is the medium through which we create knowledge, and (6) knowledge and language as transforming: knowledge and language are relational and generative, and therefore intrinsically transforming ${ }^{34}$.

Teachers' knowledge and general understanding of what is really happening in the classroom situation need to be investigated. Social constructivism is based on specific assumptions about (1) reality: social constructivists believe that reality is constructed through human activity; reality cannot be discovered, it does not exist prior to its social intervention, (2) knowledge is also a human product, and is socially and culturally constructed. Individuals create meaning through their interactions with each other and with the environment they live in, and (3) learning is a social process. It does not take place only within an individual, nor is it a passive development of behaviors that are shaped by external forces. Meaningful learning occurs when individuals are engaged in social activities ${ }^{35}$.

Knowledge is derived from interactions between people and their environments and resides within cultures. The construction of knowledge is also influenced by the inter-subjectivity formed by cultural and historical factors of the community. When the members of the community are aware of their inter-subjective meanings, it is easier for them to understand new information and activities that arise in the community. Without the social interaction with more knowledgeable others, it is impossible to acquire social meaning of important symbol systems and learn how to

31 Au, K.H., op. cit., p.300.

32 Jackson, VBR., Basic assumptions of social constructivism in international relations, (Thousand Oaks CA: Sage publications, 2006), p.6.

33 Lindgren, M., "Social constructivism and entrepreneurship: Basic assumptions and consequences for theory and research", Emerald: International Journal of Entrepreneurial Behaviour \& Research. Vol. 15 (1), 2009, p.25.

${ }^{34}$ Ibid., p.45.

${ }^{35}$ Kim, B., op. cit., p. 77. 
use them. Young children develop their thinking abilities by interacting with adults. It would be interesting to note how these assumptions play out in school classrooms.

\section{Constructivism in practice}

Constructivism as an educational theory holds that teachers should first consider their students' knowledge and allow them to put that knowledge in to practice .In other words, constructivist view as one of the leading theoretical positions in education. Since there is no universal definition of constructivism, some consider it as a theory of learning, others as a theory of knowledge; although some other scholars and theorists consider it as a theory of pedagogy. Additional views are theory of science, educational theory or an all-encompassing worldview ${ }^{36}$.

Like psychology, there has been a paradigm shift in the designed instruction which can be described as a shift from behaviorism to cognitivism and then from cognitivism to constructivism. This paradigm shift indicated that the field of education itself has undergone a significant shift in the nature of human learning and the conditions that best promote the different conditions of learning. Constructivist perspective on learning have also become so influential in the past twenty years that they represent a paradigm shift in the epistemology of knowledge and theory of learning ${ }^{37}$.

Educational constructivism itself includes a number of variations and the two most popular types of these variations are: (1) Jean Piaget's personal constructivism, and (2) Lev Vygotsky's social constructivism ${ }^{38}$. The discovery is the most important and fundamental basis of learning ${ }^{39}$. Cognitive development primarily as a function of external factors such as cultural, historical, and social interaction rather than of individual construction. Vygotsky believes that people master their behavior through psychological tools and he introduces language as the most important psychological tool. Many educators agree with the importance of culture in construction of knowledge, yet emphasize that pedagogical theories such as constructivism don't consider the deep impact of culture on learning and knowledge $e^{40}$.

\section{Constructivist tips for teaching}

As the name implies, the constructivist view of learning is concerned with how learners construct an understanding of the world. The theory proposes that meaning and understanding are built up in a process that depends on the existing knowledge foundations and cognitive operations of each individual and the learning activities they engage in. Sensory stimuli and experience must be filtered through the learners' own personal knowledge constructs, to be assimilated into their conceptual frameworks in a process that enables the individual to find meaning in the world. Crucially, this process also involves modifying, demolishing and accommodating mental frameworks that are no longer meaningful. Implicit in the theory is that genuine understanding

${ }^{36}$ Mvududu NH \& Thiel-Burgess J., "Constructivism in practice: The case for English language learners", International Journal of Education, 4(3), 2012, p.109.

37 Cooper, P.A., "Paradigm shifts in designed instruction: From behaviorism to cognitivism to constructivism", Educational Technology, 33(5), 1993, p.13.

${ }^{38}$ Phillips, DC., Constructivism in education: Opinions and second opinions on controversial issues. Ninety-ninth yearbook of the national society for the study of education, (University of Chicago Press: South Langley Avenue, 2000), p.432.

${ }^{39}$ Piaget, J \& Inhelder, B., The psychology of the child, (New York: Basic Books, 1969), p.83.

40 Bailey F \& Pransky K., “Are other people's children' constructivist learners too?”, Theory into practice, 44(1), 2005, p.19. 
cannot be simply transmitted or copied from one brain to another without the receiving brain actively engaging in the process.

Constructivist theory is associated with an evolutionary perspective that sees learning and the creation of mental models as an adaptation to the environment ${ }^{41}$. From a philosophical point of view, Constructivism can be traced to Kantian epistemology where Empiricism and Rationalism are synthesized ${ }^{42}$. Its psychological basis can be found in the study of Piaget who used the previously mentioned concepts of assimilation and accommodation to underpin his theory of cognitive development ${ }^{43}$. Another strand in the origins of constructivist theory derives from the writings of Dewey (1938) who stressed the importance of the learner's active involvement in the learning process and proposed that learners should be 'actors' rather than 'spectators'. He stressed the importance of learning as an active social process but also introduced the idea of the 'spiral' curriculum where learners revisit previously learned material and build on it. ${ }^{44}$

Constructivist theory is associated with an evolutionary perspective that sees learning and the creation of mental models as an adaptation to the environment ${ }^{45}$. From a philosophical point of view, Constructivism can be traced to Kantian epistemology where Empiricism and Rationalism are synthesized ${ }^{46}$. Its psychological basis can be found in the study of Piaget who used the previously mentioned concepts of assimilation and accommodation to underpin his theory of cognitive development ${ }^{47}$. Another strand in the origins of constructivist theory derives from the writings of Dewey (1938) who stressed the importance of the learner's active involvement in the learning process and proposed that learners should be 'actors' rather than 'spectators'. He stressed the importance of learning as an active social process but also introduced the idea of the 'spiral' curriculum where learners revisit previously learned material and build on it ${ }^{48}$.

${ }^{41}$ Plotkin, H., Darwin machines and the nature of knowledge, (London: Penguin, 1994), p.92.

${ }^{42}$ Kelly, AV., Knowledge and curriculum planning, (London: Harper \& Row, 1986), p.193.

${ }^{43}$ Chapman, M.,Constructive evolution, (Cambridge: Cambridge University Press, 1988), p.102.

${ }^{44}$ Chapman, M., op. cit., p.103.

${ }^{45}$ Plotkin, H., Darwin machines and the nature of knowledge, (London: Penguin, 1994), p.92.

${ }^{46}$ Kelly, AV., Knowledge and curriculum planning, (London: Harper \& Row, 1986), p.193. p.102.

${ }^{47}$ Chapman, M.,Constructive evolution, (Cambridge: Cambridge University Press, 1988),

${ }^{48}$ Chapman, M., op. cit., p.103. 
Tip 1

\section{Ascertain and activate prior knowledge}

If learning is about building on existing knowledge then an effective teacher needs to be aware of the background knowledge of their students. This may be found out from an overall familiarity with the curriculum and from knowledge of pre-requisite qualifications for a course. It is also readily uncovered by good questioning technique at the beginning of a teaching session.

Students may have prior knowledge but could be unaware of it or have forgotten it. An effective teacher activates students' prior knowledge at the beginning of a teaching session by reviewing previous work or by asking pertinent questions. This process brings relevant knowledge to the surface and places it on the 'mental desktop'. It is an important implication of the constructivist approach to recognise that activating prior knowledge may bring incorrect conceptual understanding to the surface, which will have to be dealt with and maybe challenged later. An important principle of adult learning is that the prior knowledge and experience of individuals can become a valuable educational resource used, for example, by a group of learners. Ascertaining, activating and acknowledging prior learning enables the teacher to begin the process of relating to learners by demonstrating empathy and respect, an important attribute of Humanistic learning theory to be described later.

\section{Tip 2}

\section{Build on existing knowledge and challenge misconceptions}

The acquisition of new knowledge can only be mediated by existing knowledge; the unknown can only be made sense of in terms of the known. Therefore, it is essential that teachers introduce and explain new concepts using knowledge that students already possess and by using analogy and metaphor to help build scaffolding and bridges to new understanding. In this respect, the context and 'situation' of learning is extremely important. Teachers should not only make cognitive connections to new learning but the importance and relevance of the learning should also be emphasized to ensure that personal and affective connections are made.

Dewey asserted that some of the most powerful learning occurs when students are in a state of uncertainty. This leads to 'cognitive dissonance' and a desire to resolve conflict and achieve a sense of mental equilibrium. Challenge should lead to curiosity and investigation. Teachers should structure learning situations in such a way that erroneous or out-moded conceptions are challenged and confronted by empirical evidence, demonstrations or alternative frameworks with greater explanatory power. Students should be given specifically designed problems or scenarios ${ }^{49}$.

Tip 3

Facilitate the social construction of meanings using group work. Stress the context and the 'situation'

The work of Vygotsky and of the later Piaget stressed the importance of the interpersonal and social nature of learning. By means of social interaction and the use of language learners develop and elaborate their cognitive skills and their knowledge base. Learners can be helped to build

${ }^{49}$ Chapman, M., op. cit., p.105. 
across the 'zone of proximal development' where they are helped in achieving a higher level of understanding by the mental scaffolding provided by a 'more knowledgeable other', a teacher or facilitator $^{50}$.

The social context of learning is therefore of great importance. Learning is a function of the interaction between the individual, other people and the environment. He emphasized the importance of role models for learners and the opportunities for vicarious learning by observing the behavior of others ${ }^{51}$. This implies that individual understanding, making sense of the world and searching for meaning, is facilitated by interpersonal communication and learning together in groups. Students should therefore be given oral tasks that encourage them to use new terminology and concepts in group situations, elaborating and refining their conceptual understanding by critically exploring the views of others. Teachers and mentors need to model appropriate behavior and learners need to be allowed to participate in authentic learning activities situated in the culture to which they will eventually become members ${ }^{52}$.

\section{$\operatorname{Tip} 4$}

\section{Use active learning techniques}

The activation of prior learning by means of questioning, the generation of cognitive dissonance and its resolution by investigation, the importance of group work, social interaction and discussion all point in the direction of active learning techniques. Constructivist theory implies that effective learning should be learning by doing, applying knowledge and problem solving. Clearly, there are occasions when information might need to be given in a more formal or didactic way but constructivist theory suggests that it should then be handled and used. There is no better way than by ensuring that new knowledge is applied in authentic problem solving activities. It is here that the vertical integration of the medical curriculum becomes important so that all learning can be clinically contextualized.

\section{Tip 5}

Encourage learners to think about how they learn and give learners responsibility for their learning

The construction of understanding is facilitated by reflecting on the process of learning itself, a task known as 'metacognition'. By encouraging students to become aware of how they construct their own learning they can identify the environmental, social and personality factors that influence their learning. This might involve students taking a number of psychometric tests to

${ }^{50}$ Wertsch, J.V., Vygotsky and the social formation of mind, (Cambridge, MA: Harvard University Press, 1985), p.94.

${ }^{51}$ Bandura, A., Social learning theory, (Englewood Cliffs, NJ: Prentice-Hall, 1977), p.219.

${ }^{52}$ Lave J, and Wenger E., Situated learning: Legitimate peripheral participation, (Cambridge: Cambridge University Press, 1991), p.92. 
identify their preferred 'learning style' although caution needs to be taken with the validity of some of these instruments ${ }^{53}$.

The most important factor influencing learning is what the learner already knows. Not only is this statement a succinct encapsulation of the main principle of Constructivism it also implies that the learner is at the heart of learning. If effective learning involves personal construction then learners must take responsibility for this fundamental process. This is essentially the most important 'metacognitive' concept that learners need to accept, hence they should abandon a passive, 'spoon-feeding' attitude and adopt a more collaborative, active approach to learning with their teachers. For teachers, Ausubel's statement implies 'learner centeredness' and suggests that they should be sensitive to the background knowledge of the student and should build on this as previously described $^{54}$.

\section{Tip 6}

\section{Ensure learners get the experiences they need}

Individuals need to ensure they get the experiences they need either individually or as part of communities of practice. There may be educational structures that enable this process or the individual might need to exercise autonomy and assertiveness in ensuring that appropriate experiences are obtained. Useful experiences should be authentic and challenging and should generate problems, questions and possibly cognitive dissonance. Experiences could be enhanced by social interaction, activity and discussion. Some experiences are entirely cognitive but they can also involve practical skills, feelings and emotions. Some experiential learning is collaborative and participative and hence takes place through social interaction.

\section{Tip 7}

\section{Reflection is helped by log-books, portfolios and feedback}

Possibly one of the most important aspects of ELT is its emphasis on reflection. Experience is transformed into learning by reflection which may take place in the individual either unconsciously or consciously. This process can importantly be enhanced by interacting with another individual such as a facilitator, teacher, mentor, master or expert. Reflection can also be enhanced by writing, leading to the development of diaries and portfolios ${ }^{55}$. Encouraging reflection leads to the development of Reflective Practice which is an important component of professionalism. The ubiquitous educational method of using portfolio-based learning coupled to appraisal and mentoringcan be traced directly to the work of David Kolb as it follows from the cyclical mode of ELT. Formal mechanisms, such as regular appraisal or supervisory meetings with

${ }^{53}$ Coffield F, Moseley D, Hall E, Ecclestone K., Should we be using learning styles? What research has to say to practice, (London: Learning and Skills Research Centre, LSDA, 2004), p.203.

${ }^{54}$ Ausubel, D.P., Educational psychology: A cognitive view. New York: Holt, Reinhart, and Winston, 1968), p.74. 2002), p.49.

${ }^{55}$ Hillier, Y., Reflective teaching in further and adult education, (London: Continuum, 
a mentor or trainer, where a portfolio or reflective diary can be discussed and future actions discussed and planned, is a major component of professional development programmes ${ }^{56}$.

Tip 8

\section{Build up mental models, practical skills and attitudes}

It is important to recognize that not only are mental models constructed by reflection on experience but so are practical skills and attitudes. There should be adequate opportunities for learners to map their experiences onto the experiences of others recorded in text-books and the 'literature'. Learners should acknowledge that their own mental frameworks are socially connected to the external world of recorded knowledge which they are attempting to internalize.

\section{Tip 9}

\section{Allow learners to engage in hypothesis testing and action planning}

Learners need opportunities to test out and question their growing body of knowledge, skills and attitudes. They need to talk and debate with facilitators and other learners. They may need to be able to test out their ideas and hypotheses in practical environments. They may need to create action plans for future experiences and may require advice and support from facilitators and mentors.

\section{Tip 10}

\section{Respect learners and acknowledge who they are and where they are coming from}

Adult learners, in particular, bring their own learning resources with them in the form of their educational background, life experiences and personal biography. Teachers and facilitators should acknowledge, respect and utilize this resource in their teaching and learning activities. Within a defined curriculum framework, learners should be allowed to explore and follow their own interests as much as possible encouraging curiosity and investigation. Facilitators should demonstrate empathy, trust and respect towards their students and be personally genuine. They should encourage students to take responsibility for their own learning.

\section{Tip 11}

\section{Ensure physical, psychological and emotional needs are taken care of}

Students will not be motivated to learn if their physiological and psychological needs have not been satisfactorily dealt with. Ensure that physiological needs such as thirst, hunger and warmth are satisfied. Ensure teaching rooms have a comfortable environment. Ensure that anxiety levels are reduced and that students have psychological shelter and security. If students feel isolated and not part of the group this may inhibit their learning so ensure that interpersonal needs such as 'belonging' and being part of the group are met. Finally encourage self-esteem, selfefficacy and self-actualization by giving positive feedback, reinforcement and praise.

${ }^{56}$ White, C. S., \& Coleman, M., Early childhood education: Building a philosophy for teaching, (Upper Saddle River, N. J.: Merrill, 2000), p.168. 


\section{Tip 12}

\section{Teaching and learning is a relationship}

Learning is facilitated by a relationship between the learner and the teacher/facilitator. Teachers should learn and use students' names, take an interest in their personal as well as educational development and should be willing to take on a pastoral role in dealing with student problems. Learning environments should also be democratic places where learners and facilitators collaborate to promote individual growth and development. Learners should be members of curriculum and teaching committees.

\section{The teacher's role in a constructivist environment}

Teacher quality is the single most important determinant of student performance. This is even more significant when applying constructivism. The teacher's knowledge, beliefs, and actions all affect the success of the learner. The most valuable quality of a teacher applying pedagogy based on constructivism is the "instantaneous and intuitive vision of the pupil's mind as it gropes and fumbles to grasp a new idea. Teachers should correct or warrant the knowledge a learner constructs, therefore promoting the development of powerful and effective constructions. They must direct the student to provide experiences that can question or expand upon their previous learning. Teachers must continuously reassure students that they are doing things right, that their thinking has power and their errors are correctable. Teachers should allow students to choose activities, ask students to explain answers, and prompt all students to be involved. A teacher can use invocative acts in which students are encouraged to think at less sophisticated levels of understanding or provocative acts; students are faced with dilemmas or challenges that push them forward in their understanding.

The teacher should become one of many resources that the student may learn from, engage students in experiences that challenge previous conceptions of their existing knowledge, allow student responses to drive lessons and seek elaboration of students' initial responses, allow students some thinking time after posing questions, encourage the spirit of questioning by asking thoughtful, open-ended questions, encourage thoughtful discussion among students, encourage and accept student autonomy and initiative, be willing to let go of classroom control, promote student leadership, collaboration, location of information, and taking actions as a result of the learning process, encourage students to suggest causes for events and situations and encourage them to predict consequences, extend learning beyond the classroom, not separate knowing from the process of finding out, and insist on clear expression from students because when students can communicate their understanding then they have truly learned.

Many teachers are in favor of adopting constructivist instructional approaches but are unsure of where to begin. The role of the constructivist teacher is to create a learning environment that is invigorating, interactive, immersive, and informative. The roles of teachers are didactic and wellestablished. The largest amount of teaching activity in educational settings involves telling things to students. More recent analyses of teaching indicate that little has changed since then. The role of the teacher in a constructivist environment is not just viewed with a different focus, but through a distinctively different lens. The learning that is captured within a constructivist environment is pictured as student centered, collaborative, mindson, authentic and action packed. For some teachers, this rings with the magic of beanstalk growth, while others will be disenchanted with a perceived lesser role of coach, facilitator or guide. The importance of changing the role of the teacher in the learning process has been emphasized that the teacher becomes the facilitator or 
coach. He/she does not possess all the knowledge, graciously allowing it to trickle down, to the great fortune of the learner. This may be cause for anxiety for teachers as uncertainty develops and envelops their new role.

It is important for the teacher to utilize errors as a way of providing feedback for the learners' understanding. In a constructivist environment the best hope for the educator is in the possibility of intervening in the learning that is occurring, rather than being in charge of the act of learning. If teachers desire to intervene in the learning game, they must be aware that they are not the one in possession of the puck. Teachers who are interested in assessing the degree of constructivism used within their classroom would benefit from reading, who refers to checklist.

Constructivist teachers are viewed as the "anything goes" type. Constructivism is equated with low structure and permissiveness imposing predefined learning goals or a learning method is somehow interfering with students' construction of meaning. In extreme cases, that may be true. Yet to help students become creative, some kind of discipline and structure must be provided. As the teacher relinquishes control over content, pacing, and specific activities, students need corresponding increases in decision and performance support. Poorly planned learning environments are vulnerable to failure due to lack of support, leaving students feeling stranded and faced with unreasonable performance expectations. This problem is complicated by the fact that learners differ dramatically in their need for support. Constructivism is teaching with an approach that seeks opportunities for students to analyze, investigate, collaborate, share, build and generate based on what they already know, rather than store away facts, skills, and processes they can later $\operatorname{parrot}^{57}$.

Constructivist teachers encourage and accept student independence and schema. They use raw data and primary sources, along with manipulative, interactive and physical materials. When framing task, constructivist teachers use cognitive terminology, such as classify, analyze, predict, and create. Constructivist teachers allow students' responses to drive lessons, shrift instructional strategies, and alter content; inquire about students' understandings of concepts before sharing their own understandings of those concepts; encourage students to engage in dialogue, both with the teacher and with one another; encourage student inquiry by asking thoughtful, open-ended questions and encourage students to ask questions of each other; seek explanation of students' initial responses; engage students in experiences that might produce constructions to their initial hypotheses and then encourage discussion; allow wait time after posing questions; provide time for students to construct relationships and create metaphors; and care for students' natural interest through frequent use of learning cycle model $^{58}$.

For conceptual learning occur, first, learners must play an active role in selecting and defining the activities; second, there must be suitable teacher support as learners build concepts,

${ }^{57}$ Gilakjani, Abbas Pourhosein., Leong, Lai-Mei and Ismail, Hairul Nizam., 'Teachers'

use of

p.50.

technology and constructivism", Modern Education and Computer Science, 4, 2013,

${ }^{58}$ White, C. S., \& Coleman, M., op. cit., p.185. 
values, schemata, and problem-solving abilities ${ }^{59}$. To make easy real learning, teachers need to organize their classroom and their curriculum so that students can collaborate, interact, and raise questions of both classmates and the teacher. Children's questions are important to help teachers understand developmental progression of children and how they understand literacy tasks.

\section{Student's Role}

The constructivist model views learners as vital in the process of learning language. Learners are active in seeking and constructing meaning and in seeking communication with others. Children learning language produce hypotheses and test them with the speaker in the environments. They try to combine sounds and words in different situations. Constructivists believe that this problem-solving behavior is very important in learning language. They also believe that the errors in children's speech reflect new knowledge about language rules. They also recognize the importance of social interactions in the development of language. For constructivists, many factors affect language learning, such as social, maturational, biological, cognitive, interactive, and modify one another as a child learns language. Many constructivist researchers believe that infants control much of their interaction with adults in their environments by smiling, making sounds, and repeating adult sounds to continue the interactions ${ }^{60}$.

\section{Social Interaction among Teachers}

The social constructivist theory is based on the belief that individuals actively construct knowledge and understanding and that constructing understandings of one's world is an active, mind-engaging process. In other words, information must be mentally acted upon in order to have meaning for the learner. According to constructivist views, learning involves building on the background knowledge the learner brings to the situation and restructuring initial knowledge. Since learners have different background knowledge, experience, and interests, they make different connections in building their knowledge over time. We construct our own understandings of the world in which we live. We search for tools to help us understand our experiences. To do so is human nature.... Each of us makes sense of our world by synthesizing new experiences into what we have previously come to understand ${ }^{61}$.

Within a constructivist framework, the learning of skills and concepts occur within meaningful and integrated contexts not in an isolated and hierarchical manner. Learning is built over time as initial knowledge is revised when new questions arise and old knowledge is challenged. "Deep understanding, not imitative behavior, is the goal....We look not for what students can repeat, but for what they can generate, demonstrate, and exhibit ${ }^{62}$. One way to prepare teachers to incorporate social interaction in their classrooms is to incorporate it into teacher

${ }^{59}$ Fosnot, C. T., Constructivism: Theory, perspectives, and practice, (New York, N.Y: Teachers College Press, 1996), p.207.

${ }^{60}$ Brewer, J. A., Introduction to early childhood Education: Preschool through primary grades, (Boston, M.A.: Allyn and Bacon, 2001), p.320.

${ }^{61}$ Brooks, J. G., \& Brooks, M. G., In search of understanding: The case for constructivist classrooms, Alexandria : Association for Supervision and Curriculum Development, 1993, p.1993.

${ }^{62}$ Ibid., p.16. 
education courses. When social interaction becomes part of the classroom dynamics, classrooms become active places; teachers need to experience this for themselves so they know how to create this type of learning environment in their own classrooms ${ }^{63}$.

Students are not the only ones who need to be talking and listening to one another while learning. Teachers are often left to navigate through a maze of complex activities. Teachers are bombarded by problems originating from student need and from various negotiations with students, parents, and administrators. Furthermore, curriculum is multifaceted with instruction relying on assessment, management, and effective presentation. Success depends on teachers having a thorough understanding of a variety of subject areas, learning how to reflect on their efforts, and developing problem-solving skills regarding any number of potential problems.

Encouraging social interaction among teachers is one of the most effective ways for teachers to learn creative methods to solve complex problems ${ }^{64}$. Teachers, like students, can effectively improve their learning skills by frequently discussing the dynamics of their classroom with peers experiencing the same challenges. Good teachers are highly motivated to improve the content of their curricula for their students and the quality of their interactions with parents and administrators. They will take the time to communicate with others when they see the value in the communication; they will promptly commit to educational activities they think will help them improve their instruction. Two fundamental processes that help teachers improve their skills are reflection and collaboration. Teachers need to use reflection to evaluate and inform their practices and use collaboration to learn to negotiate effective interactions among themselves, the students, parents, and administration ${ }^{65}$. Pre-service and in-service courses should focus on developing teachers who have a deeper understanding of themselves as educators and of the students they educate. These authors state that effective professional development must "be collaborative, involving a sharing of knowledge among educators and a focus on teachers' communities of practice rather than on individual teachers ${ }^{66}$.

Furthermore, they argue that teachers learn by doing, reading, and reflecting (just as students do); by collaborating with other teachers. This kind of learning enables teachers to make the leap from theory to accomplished practice. In addition to a powerful base of theoretical knowledge, such learning requires settings that support teacher inquiry and collaboration and strategies grounded in teachers' questions and concerns. To understand deeply, teachers must learn about, see, and experience learning-centered and learner-centered teaching practices ${ }^{67}$.

${ }^{63}$ Darling-Hammond, L., \& McLaughlin, M.W., "Policies that support professional development in an era of reform", Phi Delta Kappan, 76(8), 1995, p.600.

${ }^{64}$ Ibid., p.568.

${ }^{65}$ Askell-Williams, H., Murray-Harvey, R., \& Lawson, M.J., "Teacher Education Students' Reflections on how Problem-Based Learning Has Changed Their Mental Models About Teaching And Learning", The Teacher Educator, 42 (4), 2007, p.249.

${ }^{66}$ Darling-Hammond, L., \& McLaughlin, M.W., op. cit., p.569.

${ }^{67}$ Ibid., p.600. 
A goal of teacher education programs should be to present curriculum in such a way as to teach the necessity of social interaction. Pre-service and in-service programs need to model how social interaction encourages collective problem solving and knowledge sharing ${ }^{68}$.

\section{Implications}

Social interaction among pre-service and in-service teachers enhances and improves their skills as teachers and learners. Pre-service teachers benefit from working with other students who model how to teach and reflect on one's experiences, and in-service teachers learn to refine their craft of teaching from collaborating with other teachers - teachers at the same grade-level, at different grade-levels, and specialists. For students, the typical lecture, note-taking, and exam format does not model the process we ultimately want to see in the classroom. We want school classrooms active and engaging. To teach our pre-service teachers how to do this, we want to model a socially-interactive process that teaches our students to become active learners.

For teachers, the traditional workshop format does not follow what we know to be good teaching practice ${ }^{69}$. Professional development is "not an event, it's a process". The professional development paradigm in education, where a specialist presents a workshop to a group of teachers, often does not translate into improved teaching in the classroom. This format usually requires the teacher to work in isolation or in a group on activities outside the context of a classroom of students. A more successful manner of teacher development should consider how teachers develop insights into the craft of teaching and how they change their behavior to improve their instructional techniques or strategies ${ }^{70}$. Learning is individualized, constructed, interactive, emotional, and social. These characteristics are similar among all types of learners. In short, teachers learn in the same manner as their students ${ }^{71}$. Teachers need time and support to re-examine, redefine, and reabsorb what it means today to be a student who is responsible, who takes charge, and who selfregulates in the context of today's changing learning environment. This rethinking process may help teachers both foster lifelong learning in their students as well as realize the goal themselves ${ }^{72}$.

The components for successful teacher development need to include open conversation and dialogue, collaboration, and knowledge of subject. Teachers, like students, learn best when motivated to learn and are actively engaged in the learning process. Teachers need to commit to become independent learners, self-motivated to improve their teaching, and to test their ideas in real-life contexts. To improve their instructional behavior, teachers should self-analyze and reflect

${ }^{68}$ Ibid., p.601.

${ }^{69}$ Borko, H., "Professional development and teacher learning: Mapping the terrain", Educational Researcher, 33 (8), 2004, p.7.

${ }^{70}$ Harwell, S.H., Teacher professional development: It's not an event, it's a process, (Waco, TX: CORD, 2003), p.420.

71 Page, B., "12 things teachers must know about learning", Education Digest, 75 (8), 2010, p.54.

72 Buchler, B., Critical issue: Terms of engagement-rethinking teachers' independent learning traits. North Central Regional Educational Laboratory, (2013), p.1. 
when evaluating their teaching. They must be open to the comments and ideas offered from observing teachers and be willing share their ideas and evaluations when observing other teachers.

Learning is a constructive process where teachers try out specified activities in the classroom with students and then debrief the results with other teachers in the same classroom ${ }^{73}$. Teachers must be able to converse honestly and address issues such as what are the best ways to teach a child, group of children, or class. Teachers are generally eager to talk about teaching with others; but, rarely do teachers share their thoughts and ideas about teaching and practice ways to improve their skills in a context of classroom students and other teachers ${ }^{74}$.

\section{Theoretical perspectives on cooperative learning}

While there is a general consensus among researchers about the positive effects of cooperative learning on students' achievement, there is a controversy about why and how they affect achievement and under what conditions they have these effects. In earlier work, Slavin identified motivationalist, social cohesion, cognitive-developmental and cognitive-elaboration as the four major theoretical perspectives held by different researchers on the achievement effects of cooperative learning.

The motivationalist perspective presumes that task motivation is the single most impactful part of the learning process, asserting that the other processes such as planning and helping are driven by individuals' motivated self interest. Motivationalist scholars focus especially on the reward or goal structure under which students operate, even going so far as to suggest that under some circumstances, interaction may not be necessary for the benefits of cooperative goal structures to manifest.

By contrast, the social cohesion perspective (social interdependence theory) suggests that the effects of cooperative learning are largely dependent on the cohesiveness of the group. In this perspective, students help each other to learn because they care about the group and its members and come to derive the benefits of self-identity from group membership. The two cognitive perspectives focus on the interactions among groups of students, holding that these interactions themselves lead to better learning and thus better achievement. Within the general cognitive heading, the cognitive developmentalists attribute these effects to processes outlined by scholars such as Piaget and Vygotsky. Vygotsky's work stressed benefits of collaborating with a more expert peer because what a student carries out jointly with another could be incorporated into his or her individual repertoire. Piaget's work stressed the benefits of cognitive conflicts among students that expose students' misconceptions and lead to higher-quality understandings. Work from the cognitive elaboration perspectives asserts that learners must engage in some manner of cognitive restructuring of new materials in order to learn them. Cooperative learning is said to facilitate that process ${ }^{75}$.

The cognitive elaboration perspective instead asserts that learners must engage in some manner of cognitive restructuring (elaboration) of new materials in order to learn them; cooperative learning is seen to facilitate that process. Both the Johnsons (1993) and Slavin (1987)

\footnotetext{
${ }^{73}$ Borko, H., op. cit., p.5.

${ }^{74}$ Ibid., p.13.

${ }^{75}$ Li, M. P. \& Lam, B. H., Cooperative learning. (The Hong Kong Institute of
} Education, 2013), p.137. 
have developed frameworks that combine their motivational approaches with cognitive theories ${ }^{76}$. Slavin et al. (2003) have proposed a theoretical model intended to acknowledge the contributions of each of the major theoretical perspectives and the likely role that each plays in co-operative learning processes. They explore conditions under which each may operate, and suggest research and development needed to advance co-operative learning scholarship so that educational practice may truly benefit the lessons of thirty years of research ${ }^{77}$.

A model of how co-operative learning might improve learning, adapted from Slavin (1995) depicting the main components of group learning interaction and representing the functional relationships among the different theoretical approaches. He graphs the relationship between group learning goals, motivation, and enhanced learning as presented in the Figure below. Group learning goals produce within team members the motivation to learn, encourage other members to learn, and motivate members to help each other learn. Within each member deeper learning occurs as a result of peer tutoring, practice, assessment and correction ${ }^{78}$.

Figure. Integration of Theoretical Perspectives on Cooperative Learning Effects on Learning

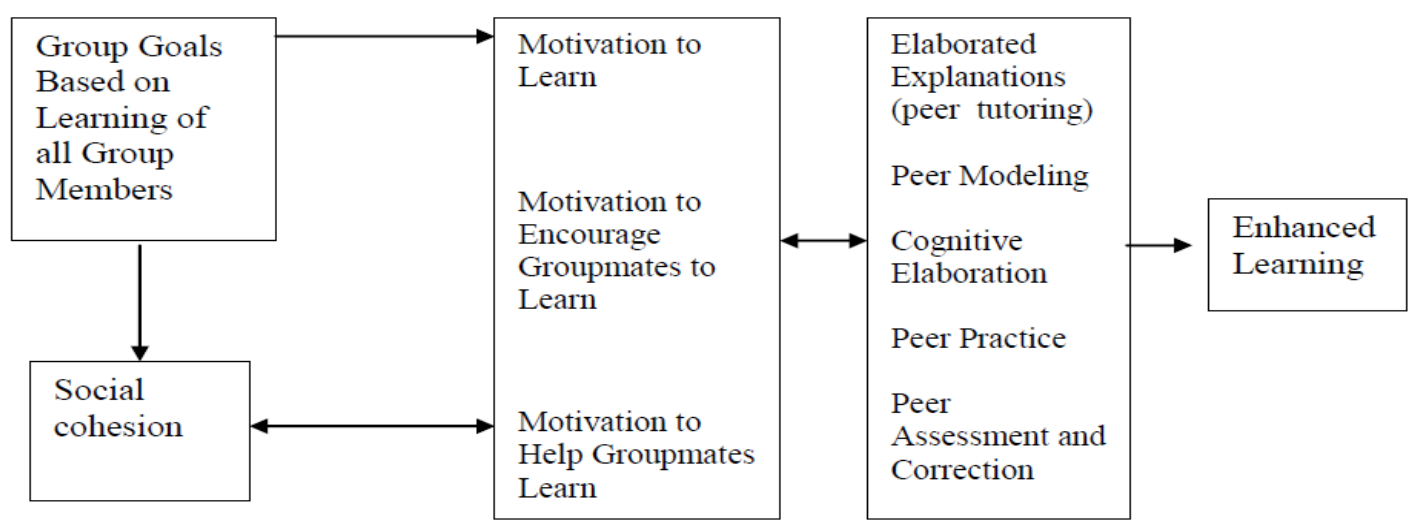

Adapted from Slavin (2011). Instruction based on cooperative learning. In R. Mayer (Ed.), Handbook of research on learning and instruction. London: Taylor \& Francis.

This diagram of the interdependent relationships among the components begins with a focus on group goals or incentives based on the individual learning of all group members. It assumes that motivation to learn and to encourage and help others to do so activates co-operative behaviors that will result in learning. This includes both task motivation and motivation to interact in the group. In this model, motivation to succeed leads directly to learning, and it also drives the behavior and attitudes that foster group cohesion, which in turn facilitates the types of group interactions - peer modeling, equilibration, and cognitive elaboration - that yield enhanced learning and academic achievement.

\footnotetext{
${ }^{76}$ Ibid., h. 130.

${ }^{77}$ Ibid., h. 135.

${ }^{78}$ Ibid., h. 140.
} 


\section{CONCLUSION}

Constructivism is one of the best described and studied learning theories in education. However, there is no single teaching and learning style, which works best for everyone. Different teaching and learning styles provide different kinds of information used for different purposes. Teachers can select their most appropriate teaching strategies to help students learn new concepts within the confines of their classroom environment.

\section{REFERENCES}

Abdal-Haqq, I., Constructivism in teacher education: considerations for those who would link practice to theory. Thousand Oaks. CA: Corwin Press, 1998.

Alesandrini, K., \& Larson, L., Teachers bridge to constructivism. Clearing-House. 75, p.118-121, 2002.

Alvermann, D.E., \& Phelps, S.F., Content reading and literacy: Succeeding in today's diverse classrooms (4th ed.). Boston: Allyn Bacon, 2005.

Askell-Williams, H., Murray-Harvey, R., \& Lawson, M.J., Teacher education students' reflections on how problem-based learning has changed their mental models about teaching and learning. The Teacher Educator, 42 (4), p.237-263, 2007.

$\mathrm{Au}$, K.H., Social Constructivism and the School Literacy Learning of Students Diverse Backgrounds. Journal of Literacy Research.Vol 7 (30):p. 29-79, 2005.

Ausubel DP., Educational psychology: A cognitive view. New York: Holt, Reinhart, and Winston, 1999.

Bailey F \& Pransky K., Are other people's children' constructivist learners too? Theory into practice, 44(1), p.19-26, 2005.

Bakkenes, I., De Brabander, C., \& Imants, K., Teacher isolation and communication network analysis in primary schools. Education Administration Quarterly, 35 (2), p.166-202, 1999.

Bandura A., Social learning theory. Englewood Cliffs, NJ: Prentice-Hall, 1977.

Borko, H., Professional development and teacher learning: Mapping the terrain. Educational Researcher, 33 (8), p.3-15, 2004.

Brewer, J. A., Introduction to early childhood Education: Preschool through primary grades. Boston, M.A.: Allyn and Bacon, 2001.

Brooks, J. G., \& Brooks, M. G., In search of understanding: The case for constructivist classrooms. Alexandria, VA: Association for Supervision and Curriculum Development, 1993.

Bruner, J. S., Toward a theory of instruction. Cambridge: Harvard University Press, 1966.

Bruner, J. S., The culture of education. Cambridge: Harvard University Press, 1996. 
Buchler, B., Critical issue: Terms of engagement-rethinking teachers' independent learning traits. North Central Regional Educational Laboratory. Retrieved from http://www.ncrel.org/sdrs/areas/issues /educatrs/profdevl/pd400.htm, 2003.

Chapman M. Constructive evolution. Cambridge: Cambridge University Press, 1988.

Coffield F, Moseley D, Hall E, Ecclestone K., Should we be using learning styles? What research has to say to practice. London: Learning and Skills Research Centre, LSDA, 2004.

Cooper PA., Paradigm shifts in designed instruction: From behaviorism to cognitivism to constructivism. Educational Technology, 33(5), p.12-19, 1993.

Darling-Hammond, L., \& McLaughlin, M.W., Policies that support professional development in an era of reform. Phi Delta Kappan, 76(8), p.597-604, 1995.

Dixon-Krauss, L., Vygotsky in the classroom:Mediated literacy instruction and assessment. White Plains, N.Y.: Longman, 1996.

Fosnot, C. T., Constructivism: Theory, perspectives, and practice. New York, N.Y: Teachers College Press, 1996.

Frey, N., Fisher, D., \& Allen, A., Productive group work in middle and high school classrooms. In S. Parris, D. Fisher, \& K. Headley (Eds.), Adolescent literacy: Effective solutions for every classroom (pp. 70-81). Newark, DE: International Reading Association, 2009.

Gagnon, G. W., \& Colley, M., Constructivist learning design. URL (last checked 6 February 2017). http://www.prainbow.com/cld/clds.html, 2001.

Gay, L .R., Educational research. competencies for analysis and application. New Jersey: Prentice-Hall. Inc, 2001.

Gee, J. P., Reading as situated language: A sociocognitive perspective. Journal of Adolescent \& Adult Literacy, 44 (8), 714-725, 2001.

Gilakjani, Abbas Pourhosein., Leong, Lai-Mei and Ismail, Hairul Nizam., Teachers' use of technology and constructivism. Modern Education and Computer Science, p.49-63. Retrieved from http://www.mecs-press.org/, 2013.

Goodlad, J., A place called school. New York: McGraw-Hill, 1984.

Goodman, K., What's whole in whole language. Portsmouth, NH: Heinemann, 1986.

Harwell, S.H., Teacher professional development: It's not an event, it's a process. Waco, TX: CORD, 2003.

Hillier Y., Reflective teaching in further and adult education. London: Continuum, 2002.

Hurst, B., Person working equals person learning. Journal of Reading Education, 23 (3), p.23-24, 1998.

Hurst, B., My journey with learning logs. Journal of Adolescent \& Adult Literacy, 49 (1), p.42-46, 2005. 
Hussain, I., \& Sultan, S., Learning by doing: Outcomes of teaching a research course through group activities. Proceedings of the Annual International Conference on Computer Science Educa-tion: Innovation \& Technology (CSEIT) 2010, Singapore City: Global Science and Technology Forum, 6-7 December 2010.

Jackson, VBR., Basic assumptions of social constructivism in international relations. Thousand Oaks CA. Sage publications, 2010.

Johnson, D. W., \& Johnson, F. P., Joining together: Group theory and group skills (7th ed.). Englewood Cliffs, NJ: Prentice Hall, 1999.

Kasten, W.C., Learning is noisy; the myth of silence in the reading-writing classroom. In J.R. Paratore, \& R.L. McCormack (Eds.), Peer talk in the classroom: Learning from research (pp. 88-101). Newark, DE: International Reading Association, 1997.

Kelly AV. Knowledge and curriculum planning. London: Harper \& Row, 1986.

Kember D. (ed.), Reflective teaching and learning in the health professions. London: Blackwell Science, 2001.

Kim, B., Social constructivism.New York: Routledge, 2006.

Lave J, and Wenger E,. Situated learning: Legitimate peripheral participation. Cambridge: Cambridge University Press, 1991.

Li, M. P. \& Lam, B. H., Cooperative learning. The Hong Kong Institute of Education All rights reserved. www.ied.edu.hk/aclass/, 2013.

Li, W., Constructivist learning systems: A new paradigm. In-ternational Conference on Advanced Learning Techniques, Madison, 6-8 August 2001

Lindgren, M., Social constructivism and entrepreneurship: Basic assumptions and consequences for theory and research. Emerald: International Journal of Entrepreneurial Behaviour \& Research. Vol. 15 (1): p.25-47, 2009.

Lord, T., Travis, S., Magill, B., \& King, L., Comparing student-centered and teacher-centered instruction in college biology labs. Indiana, PA: Indiana University of Pennsylvania, 2009.

Martin, R.E. Sexton, C. Franklin, T. Gerlovich, J, and McElroy, D. Teaching science for all children. Boston: Allyn and Bacon,. 1994.

Moon JA., Reflection in learning and professional development. London: Kogan Page, 1999.

Moon JA., A handbook of reflective and experiential learning: Theory and practice. London: Routledge Falmer. 2004.

Mvududu NH \& Thiel-Burgess J., Constructivism in practice: The case for English language learners. International Journal of Education, 4(3), p.108-p118, 2012.

Page, B., 12 things teachers must know about learning. Education Digest, 75 (8), p.54-56, 2010. 
Phillips DC., Constructivism in education: Opinions and second opinions on controversial issues. Ninety-ninth yearbook of the national society for the study of education. University of Chicago Press, Order Dept., 11030 South Langley Avenue, Chicago, IL 60628, 2000.

Piaget J \& Inhelder B. The psychology of the child. New York: Basic Books., 1969.

Piaget, J., Science of education and the psychology of the child. New York: Penguin, 1979.

Plotkin H., Darwin machines and the nature of knowledge. London: Penguin, 1994.

Pratton, J., \& Hales, L. W., The effects of active participation on student learning. Journal of Educational Research, 79, 210-215, 1986.

Richardson K., Models of cognitive development. Hove: Psychology Press, 1998.

Roopnarine, J. L., \& Johnson, J. E., Approaches toearly childhood education. Upper Saddle River, N.J.: Merrill, 2000.

Routman, R., Reading essentials: The specifics you need to teach reading well. Portsmouth, NH: Heinemann, 2003.

Routman, R., Writing essentials: Raising expectations and results while simplifying teaching. Portsmouth, NH: Heinemann, 2005.

Santmire, T. E., Giraud, G., \& Grosskopf, K, An experimental test of a constructivist educational environment. Annual Meeting of the American Educational Research Association, Montreal, 19-23 April 1999.

Sigel, I. E., \& Cocking, R. R., Cognitive development from childhood to adolescence: A constructivist perspective. New York: Holt, Rinehart \& Winston, 1977.

Sims, R., Dobbs. G., \& Hand, T, Proactive evaluation: New perspectives for ensuring quality in online learning application. Conference proceedings of the 18th Annual Conference of the Australlian Society for Computers in Learning in Tertiary Education (AS-CILITE), Meeting at the Crossroads, 509-517, 1977.

Spiro, P., Constructivism in practice: The case study for meaning-making in the virtual world. Hillsdale. Lawrance Erlbaum Publications, 2006.

Vacca, R.T., \& Vacca, J.L, Content area reading: Literacy and learning across the curriculum (7th ed.). Boston: Allyn and Bacon, 2002.

Vacca, R.T., Vacca, J.L., \& Mraz, M., Content area reading: Literacy and learning across the curriculum (10th ed.). Boston: Pearson, 2011.

Vygotsky, L. S., The problem of environment. In R. van der Veer, \& J. Valsiner (Eds.), The Vygotsky reader. Cambridge: Black-well, 1994.

Vygotsky, L. S., Mind in society. Cambridge: Harvard University Press. 1978.

Wertsch JV., Vygotsky and the social formation of mind. Cambridge, MA: Harvard University Press, 1985. 
White, C. S., \& Coleman, M, Early childhood education: Building a philosophy for teaching. Upper Saddle River, N. J.: Merrill, 1985.

Wilkinson, I.A.G., Soter, A.O., \& Murphy, P.K., Developing a model of quality talk about literacy text. In M.G. McKeown \& L. Kucan (Eds.), Bringing reading research to life (pp.142169). New York: The Guilford Press, 2010. 